\author{
Torma András
}

\title{
KÉRDÉSEK ÉS VÁLASZOK (?) A MAGYAR FELSŐOKTATÁSBAN: REKTOR KONTRA KANCELLÁR
}

\author{
Questions and Answers (?) in the Hungarian Higher Education: Rector vs. Chancellor
}

Prof. Dr. Torma András CsC, egyetemi tanár, rector emeritus, Miskolci Egyetem, Állam- és Jogtudományi Kar, Államtudományi Intézet, Közigazgatási Jogi Tanszék, rektorma@uni-miskolc.hu

A 21. század az információs forradalom évszázada, amikor nem az a kérdés, hogy lesz-e, van-e információ, hanem az, hogy a rendelkezésre álló forrásokban hol találom meg azt. A jelen tanulmány szerzője könnyü helyzetben volt ebböl a szempontból, hiszen magyar joganyagot vizsgált. Olyan forrásból merített tehát, amely Magyarországon mindenki által, korlátlanul és ingyenesen hozzáférhetö. A tanulmány középpontjában egyetlen törvény, a felsőoktatásról szóló 2011. évi CCIV. törvény és annak gyakorlata áll. Az a jogszabály, amely a hatálybalépését követö tíz évben kilencszáz (!) joghelyen módosult, ennélfogva bizonyosan nem tekinthetö a magyar jogalkotás kősziklájának. Másfelöl az a gyakorlat, a gyakorlati tapasztalatok sokasága, amelynek a szerző alanya volt, hiszen 2012. július 1. és 2013. augusztus 15. között a Miskolci Egyetem Állam-és Jogtudományi Karának dékánja, ezt követöen pedig hét éven át az Egyetem rektora volt. Ebböl az aspektusból vizsgálja a szerzö azokat a joghelyeket, amelyeket problémásnak itélt, különös figyelemmel a törvény 2014. évi módositására, illetve a kancellári rendszer bevezetésére.

\section{Kulcsszavak}

felsőoktatás, magyar felsőoktatás, felsőoktatási szabályozás, felsőoktatási törvények, felsőoktatási autonómia, felsőoktatási vezető, rektor, kancellár

The $21^{\text {st }}$ century is the century of the information revolution. The question is not whether there is information, but where to find it in the available resources. The author of the study was in an easy position in this respect, as he examined Hungarian legislation. It is based on a source that is accessible to everyone in Hungary, unlimited and free of charge. The study focuses on a single law, Act CCIV of 2011 on National Higher Education and its practice. In the ten years following its entry into force, the legislation has been amended in nine hundred (!) instances and, therefore, 
cannot be considered the rock of Hungarian legislation. The author has extensive experience, because he was the dean of the Faculty of Law of the University of Miskolc from 1 July 2012 to 15 August 2013, and then, he was the Rector of the University of Miskolc for seven years. The author examines the problematic jurisdictions from this aspect, with special attention to the amendment of the law in 2014 and the introduction of the chancellor system.

\section{KeYwords:}

higher education, Hungarian higher education, higher education regulation, higher education laws, higher education autonomy, higher education leader, rector, chancellor 


\section{BEVEZETÉS}

A magyar felsőoktatás rendkívül összetett és bonyolult rendszer, amelynek alapvető feladata - a tudományos kutatás mellett - a felsőfokú szakemberképzés. Úgy ítélem meg, hogy az ezzel kapcsolatos kérdések és válaszok megfogalmazásakor két olyan tényből, körülményből indokolt kiindulni, amelyek meghatározzák és egyben be is határolják a jelen dolgozat kereteit - formai és tartalmi értelemben egyaránt.

Formai értelemben azért, mert a tanulmány terjedelme mindössze fél ív lehet, vagyis a terjedelem meglehetősen szűkre szabott, legalábbis számomra, egy közjoggal foglalkozó egyetemi oktató számára. Ez természetesen kihatással van a tartalomra is, amennyiben nem vállalkozhatom valamiféle teljes körü számbavételre és részletes elemzésre, hanem csupán az általam legfontosabbnak ítélt kérdések és válaszok (?) felvillantására.

A tartalmi értelemben vett behatárolás pedig a személyemhez kötődik. ${ }^{1}$ 1980-ban fejeztem be egyetemi (jogi) tanulmányaimat, és 1984-ben kezdtem meg egyetemi oktatói pályámat az akkori Nehézipari Műszaki Egyetem (1990-től Miskolci Egyetem) Államés Jogtudományi Kar Âllamtudományi Tanszékén. Akkoriban a tanszék az államigazgatási jog, az államjog, a pénzügyi jog és a nemzetközi jog oktatásáért és kutatásáért volt felelős, a tanszékvezető pedig néhai Prof. Dr. Kalas Tibor, az intézet, majd a kar egyik alapító professzora volt. Az államigazgatási jogot (mai nevén: közigazgatási jogot) kezdtem oktatni, később azonban egy egész sor más diszciplínát is oktattam, kutattam. 1993-ban szereztem kandidátusi tudományos fokozatot, 2002-ben habilitáltam és 2003-ban nyertem egyetemi tanári kinevezést. Az egyetemi vezetői pálya minden lépcsőjét bejárva, 1995-ben tanszékvezető, 2004-ben dékánhelyettes, 2007-ben intézetigazgató, 2012-ben az Államés Jogtudományi Kar dékánja, 2013-ban pedig a Miskolci Egyetem rektora lettem. 2021-től az Egyetem rector emeritusa és a Közigazgatási Jogi Tanszék professzora vagyok.

Mindezeket azért bocsátottam elöre, hogy kiderüljön: az utóbbi majd' 40 évben a magyar felsőoktatás világának kezdetben passzív, később aktív szereplője, formálója és alakítója voltam. Röviden: belülről ismertem - ismerem a magyar felsőoktatást. Ugyanakkor rögzítenem kell azt is, hogy a kérdésfelvetéseim és a válaszaim - sőt nézőpontom is - szükségképpen egyoldalúak és szubjektívek. Abban az értelemben legalábbis, hogy a rendszerváltás egyik vesztesének, az Észak-magyarországi Régió vezető tudásközpontjának, a Miskolci Egyetemnek a szemszögéből vizsgálom a magyar felsőoktatást, a törvényi szabályozásra és a kancellári rendszer fölállítására koncentrálva.

Itt és most - bár aktuális és logikus lenne - nem kívánok foglalkozni a Covid-19-világjárványnak a magyar felsőoktatásra gyakorolt hatásaival, mert ezt magas színvonalon már megtette például Árva Zsuzsanna professzor: Árva Zsuzsanna: A koronavírus hatása a felsőoktatási igazgatásra. In Rixer Ádám (szerk.): A járvány hosszú távú hatása a magyar közigazgatásra. Budapest, Károli Gáspár Református Egyetem, Állam- és Jogtudományi Kar Lőrincz Lajos Közjogi Kutatóműhely, 2021. 349-364. 


\section{A MAGYAR FELSŐOKTATÁS NEMZETI JOGI HÁTTERE}

Napjaink, a 20. és a 21. század egyik meghatározó sajátossága a globalizáció: az a gazdasági-társadalmi folyamat, amelynek következtében a Földgolyó különböző országai, nemzetei és gazdaságai egy világhálózatba tömörülnek, és többé-kevésbé levetvén nemzeti sajátosságaikat, egységesülnek. A globalizáció tehát olyan világjelenség, amelynek hatásai alól ma már egyetlen ország vagy nemzet sem vonhatja ki magát. Az már más kérdés, hogy a globalizáció milyen mértékben hat az adott országra vagy nemzetre.

Úgy ítélem meg, hogy a globalizációban jelölhető meg az az egyik ok, amely miatt a Föld országai a történelem folyamán különböző nemzetközi szervezeteket hoztak létre. Ilyen nemzetközi szervezet volt például a Zollverein (a német vámunió, 1834-1871), az ENSZ (1949-), továbbá a napjainkban is müködő Kereskedelmi Világszervezet (WTO, 1995-), a NATO (1949-), az OECD (1961-), az Európa Tanács (1949-), az Ázsiai Unió (2002-), az OPEC (1960-) és az Európai Unió (1993-) is. Az egyes országok szabadon döntenek abban a kérdésben, hogy csatlakoznak-e az adott nemzetközi szervezethez. Ha igen, akkor azonban a csatlakozási okmányban rendszerint kinyilatkoztatják: vállalják a vonatkozó elöírások betartását, és alávetik magukat e szervezetek döntéseinek.

Magyarország mint az ENSZ, a NATO, az Európa Tanács és egy egész sor más nemzetközi szervezet tagállama, természetesen alkalmazni köteles ezen nemzetközi szervezetek alapokmányait és az általuk kibocsátott egyezményeket, feltéve, hogy csatlakozott az adott egyezményhez. Az európai uniós tagságunk azonban különleges ebből a szempontból, mert az Unió tagállamai átruházták szuverenitásuk egy részét az Unióra. Ennek következtében az uniós jog automatikusan, a megszületésével behatol a tagállamok jogrendszerébe és elsőbbséget élvez azokkal szemben.

Mindezek figyelembevételével az egyes országok jogalkalmazói nemcsak a nemzeti jogot, hanem a nemzetközi szervezetek előírásait is alkalmazzák, alkalmazni kötelesek. Így van ez természetesen Magyarország esetében is. Ebből következően a magyar felsőoktatás helyzetének vizsgálata során indokolt lenne elemezni azt is, hogy milyen kérdések tehetők fel, és milyen válaszok adhatók a nemzetközi szervezetek vonatkozó előírásainak alkalmazása során. Nem véletlenül írja Halász professzor 2013-ban a következőket:

„A fejlett államok, ezen belül az Európai Unió tagországai többségének felsőoktatási rendszereiben az elmúlt évtizedekben nagy horderejű változások történtek [...] A nemzeti felsőoktatási rendszerekben zajló változásokat [...] egyre inkább meghatározzák a nemzeti rendszereken kívül, a felsőoktatás európai és globális rendszerében zajló folyamatok."2

Halász Gábor: A felsőoktatás globális trendjei és szakpolitikai válaszok az OECD-országokban és az Európai Unióban. In Hrubos Ildikó - Luda Szilvia - Török Imre (szerk.): Intézményi menedzsment a felsőoktatásban 3. Budapest, Felsőoktatási Gazdasági Szakemberek Egyesülete, 2013. 13. 
Ennek ellenére nem foglalkozhatom a felsőoktatásra vonatkozó nemzetközi jogi előírások magyarországi érvényesülésével, mert az messze meghaladná a rendelkezésemre álló szűk kereteket. Éppen ezért a továbbiakban csupán a nemzeti jogszabályokat veszem szemügyre a magyar felsőoktatás helyzetének vizsgálata során.

Köztudomású, hogy a modern korban, a különböző államok jogrendszere piramist alkot, amelyben - a hierarchiának megfelelően - az egyes jogi normák alá-fölérendeltségben szabályozzák a társadalmi élet adott területét. A piramis csúcsán rendszerint az alaptörvény áll (amelynek neve esetleg alkotmány, vagy írott alkotmány hiányában alkotmányos törvények), alatta a törvények, azok alatt pedig a rendeletek állnak. Alapelv az, hogy a hierarchia alacsonyabb szintjén elhelyezkedő jogszabály nem lehet ellentétes a magasabb szintű jogszabállyal.

Természetesen ez Magyarország esetében is így volt és így van, azzal, hogy első írott alkotmányunk a szovjet típusú állami és gazdasági rendre történő átállás jegyében 1949-ben, a felsőoktatásról szóló első törvényünk pedig - az 1989/90. évi rendszerváltás jegyében - 1993-ban született. ${ }^{3}$ A jogtörténeti részletek mellőzésével, e körben kell utalnom arra, hogy az első felsőoktatási törvényt viszonylag hamar hatályon kívül helyezte a második, a 2005. évi CXXXIX. törvény (Ftv.), amely az Európai Unióhoz 2004-ben történt csatlakozásunk „eredménye”, e törvényt pedig igen gyorsan hatályon kívül helyezte a harmadik, a jelenleg hatályos, nemzeti felsőoktatásról szóló 2011. évi CCIV. törvény (Nftv.). Ez utóbbi a 2010. évi országgyülési választáson 2/3-os többséget szerzett FIDESZKDNP koalíció által kezdeményezett, és az Országgyülés által 2011. április 25-én megalkotott Alaptörvénynek a „Szabadság és felelősség” című rész X. cikkén alapszik. ${ }^{4} \mathrm{Az} \mathrm{Nftv}$. jelenleg hatályos 110 . $\$$-a szerint a törvény végrehajtására a Kormány 33, a felsőoktatásért felelős miniszter pedig három kérdéskörben kapott felhatalmazást. E végrehajtási jellegü jogszabályok a hatálybalépést követően meg is születtek, részletezésükkel azonban itt és most nem indokolt foglalkozni.

Ez a legszükebb értelemben felfogott nemzeti jogszabályi háttér, amelyben a magyar felsőoktatás müködött, illetve müködik. Azért csak „legszűkebb értelemben felfogott”, mert az Nftv. és végrehajtási rendeletei mellett, természetesen egyéb jogszabályok egész sora (törvények, kormányrendeletek és miniszteri rendeletek tömege) is érinti valamilyen módon és formában a magyar felsőoktatást. Például szolgálhat a közoktatási törvény, ${ }^{5}$ mivel vannak

Lásd a Magyar Népköztársaság Alkotmányáról szóló 1949. évi XX. törvényt, illetve a felsőoktatásról szóló 1993. évi LXXX. törvényt.

$4 \quad$ Az Alaptörvény X. cikke az alábbiakat rögzíti:

„(1) Magyarország biztosítja a tudományos kutatás és művészeti alkotás szabadságát, továbbá - a lehető legmagasabb szintü tudás megszerzése érdekében - a tanulás, valamint törvényben meghatározott keretek között a tanítás szabadságát. (2) Tudományos igazság kérdésében az állam nem jogosult dönteni, tudományos kutatások értékelésére kizárólag a tudomány művelői jogosultak. (3) Magyarország védi a Magyar Tudományos Akadémia és a Magyar Művészeti Akadémia tudományos és művészeti szabadságát. A felsőoktatási intézmények a kutatás és a tanítás tartalmát, módszereit illetően önállóak, szervezeti rendjüket törvény szabályozza. Az állami felsőoktatási intézmények gazdálkodási rendjét törvény keretei között a Kormány határozza meg, gazdálkodásukat a Kormány felügyeli."

Lásd a közoktatásról szóló 1993. évi LXXIX. törvényt. 
olyan felsőoktatási intézmények, amelyek fenntartói valamely közoktatási intézménynek, így természetesen kötelesek alkalmazni annak szabályait (is). Ilyen intézmény a Miskolci Egyetem is, amely a Ferenczi Sándor Egészségügyi Technikum fenntartója. További példaként szolgálhatnak azok a törvények, amelyek a mindennapok megéléséhez szorosan kötődnek: ilyen a Polgári Törvénykönyv, hiszen a felsőoktatási intézmények napi gyakorisággal kötnek szerződéseket, vagy ilyen a Munka törvénykönyve is, hiszen a felsőoktatási dolgozók jelentős - és a magánegyetemmé válás miatt egyre növekvő - nagyságrendje ma már nem közalkalmazotti jogviszonyban áll, hanem munkaviszonyban.

Ezek után leszögezhető: nem fér kétség ahhoz, hogy meglehetősen alapos és komoly jogi felkészültséget követel meg egy magyar felsőoktatási intézmény különböző szintű vezetőitől az a munkakör, amelyet betöltenek, és akkor még nem beszéltünk a közgazdasági, a humánpolitikai vagy a szoros értelemben vett szakmai ismeretekről, valamint az adott intézmény belső szabályzatairól (SZMSZ, Tanulmányi és Vizsga Szabályzat, Gazdálkodási Szabályzat stb.).

\section{KÉRDÉSEK ÉS (ADOTT ESETBEN) VÁLASZOK}

A jelen tanulmány címében a „válaszok” szó után nem véletlenül használok kérdőjelet, a jelen fejezet címében pedig azért fogalmazok a „válaszok” szó előtt zárójelben úgy, hogy „adott esetben”, mert mint senki más, természetesen én sem hordom zsebemben a bölcsek kövét. Nyilvánvalóan elöfordulhat tehát, hogy nem tudom vagy nem ismerem a választ az egyébként fontos, általam felvetett kérdésre, kérdésekre. Nézzük tehát a kérdéseket és (adott esetben) a válaszokat.

1. A 2005-ben magalkotott Ftv. 1. \$ (3) bekezdése kimondta, hogy a felsőoktatási intézmény oktatási, kutatási, szervezeti és működési, valamint gazdálkodási autonómiát élvez, és $a)-h$ ) pont alatt rögzítette azt is, hogy mit jelent az autonómia kifejezés, illetve mit ért ez alatt. Ehhez képest a 2011-ben született Nftv. 11. \$-a hallgat az autonómiáról és az a)-g) pontokban körülírja az intézmények alapvető működési szabályait. Kérdésként merül fel: miért szakít az Ftv. megoldásával az Nftv., vagyis miért „feledkezik meg” a jogalkotó a felsőoktatási intézmények autonómiájának deklarálásáról? A pontos és egyértelmü választ nem tudom, nem ismerem. ${ }^{6}$

2. Az Nftv. nem bizonyult a jogalkotás kősziklájának, hiszen az eddig eltelt rövid, mindössze tízéves funkcionálása alatt minden egyes évben, rendszerint évente többször és igenigen sok joghelyen módosult. ${ }^{7}$ Miközben az országgyűlési választásokon a FIDESZ-KDNP koalíció 2014-ben és 2018-ban is 2/3-os többséget szerzett a Parlamentben, tehát a módosítás

A felsőoktatási autonómiáról lásd például Kocsis Miklós: Társadalom - állam - felsőoktatás. A felsőoktatási autonómia értelmezési tartományai. Jogelméleti Szemle, (2010), 3; továbbá Hamza Gábor: Az egyetemi autonómia reformjának kérdéséhez. Magyar Tudomány, 175. (2014), 2. 130-139.

Az Nftv. már a hatálybalépése évében, 2012-ben is többször módosult. Lásd erről a 2012. évi CXXIII., a 2012. évi CXCVI. és a 2012. évi CCVIII. törvényt. 
gyakoriságának oka a kormányváltás nem lehetett. A módosítás gyakoriságának alátámasztására „csupán” azt említem, hogy a törvény hatályos szövegének lábjegyzete 900, azaz kilencszáz (!) joghelyen mutat ki módosítást, beiktatást, megállapítást, hatályon kívül helyezést stb., ami átlagosan évi 90, azaz kilencven (!) joghelyen történő beavatkozást jelentett a mindenkor hatályos törvényszövegbe. Minthogy az Alaptörvény B) cikke szerint Magyarország jogállam, amely - többek között - magában foglalja a jogbiztonság követelményét is, felmerül a kérdés: vajon megfelel-e a jogbiztonság (a jogállamiság) követelményének az a törvény, amely évente átlagosan 90 joghelyen módosul? A válaszom erre egyértelműen: nem. ${ }^{8}$ Itt azonban nem „csak” a jogbiztonságot mellőző jogbizonytalanságról van szó, hanem arról is, hogy a magyar felsőoktatás nagy hajóként szükségképpen lassan fordul, és amelyet egy-egy ide-oda rángató mozdulattal nem lehet, illetve nem szabad irányítani, mert annak súlyos következményei lehetnek: a hajó fölborul vagy zátonyra fut. ${ }^{9}$ Álláspontom szerint a 10 év alatt 900, illetve az évente átlagosan 90 joghelyen történt jogalkotói beavatkozás kifejezetten ide-oda történő rángatásnak tekintendő, amelynek súlyos következményei voltak, vannak, illetve lehetnek.

3. Az Nftv. nemcsak igen gyakran és igen sok joghelyen, hanem, sajnos, alapvető kérdésekben is többször módosult. Az alapvető kérdések körében csak a két legfontosabb egyetemi vezető, a rektor és a kancellár státusa körüli problémákat emelem ki.

Ami a rektort illeti: az Nftv.-t módosító, egyes oktatási tárgyú törvények módosításáról (és nem direkt a felsőoktatásról) szóló 2014. évi XXXVI. törvény hatálybalépése előtt, az Nftv. 12. $\$(3)$ bekezdés $d$ ) pontja szerint az egyetem legmagasabb szintű vezető testülete a szenátus nem választja meg, hanem csak „véleményezi a rektori pályázatokat”. A felsőoktatás körében sokan ezt az egyetemi autonómia megsértésének tekintették, és ezt jelezték is a Rektori Konferencia és az illetékes miniszter felé. Erre is figyelemmel került sor a 2014. évi XXXVI. törvény 17. \$-sal az Nftv. 12. \$(3) bekezdés $d$ ) pontjának módosítására. Ennek értelmében 2014. július 24-től a szenátus már nem véleményezi, hanem „elbírálja a rektori pályázatokat és megválasztja a rektorjelöltet”. Helyes döntés volt a jogalkotó részéről a módosítás? A válaszom egyértelmüen: igen. A magam részéről tehát egyetértettem a módosítással, és ma is úgy ítélem meg, hogy ezzel visszaállt az eredeti állapotba a szabályozás egyensúlya.

4. Ami pedig a kancellárt illeti: 2013. augusztus 15-től lettem rektor, és mint ilyen, az Nftv. 13. $\$(1)$ bekezdése szerint az intézmény elsőszámú vezetője és képviselője. Akkoriban a rektor egyedül volt az egyetemi dolgozók munkáltatója, és egyedül felelt az egyetem egészéért,

8 A jogbiztonság követelményét mint a jogállami működés egyik előfeltételét az Alkotmánybíróság már a rendszerváltást követően, igen gyorsan kidolgozta. A 9/1992. (III. 5.) számú határozatában kimondta például, hogy „a jogállam nélkülözhetetlen eleme a jogbiztonság, (ami) az állam kötelességévé teszi [...] hogy az egyes jogszabályok világosak, egyértelmüek, működésüket tekintve kiszámíthatóak és előre láthatóak legyenek".

9 A Kormány tudatában volt ennek, hiszen a 2014-ben, első olvasatban tárgyalt Fokozatváltás a felsőoktatásban. A teljesitményelvü felsőoktatás fejlesztésének irányai címü dokumentum 7. oldalán a következők szerint fogalmaz: „2030. [...] A felsőoktatás egy robosztus, nehezen változó rendszer, minden lényegi átalakuláshoz hosszú időre van szükség [...] A 2030-as dátum megengedi, hogy sokkal karakteresebben kerüljenek megfogalmazásra a szükséges beavatkozások” 
az intézmény egész életéért: oktatás - kutatás - humánpolitika - gazdálkodás - vagyonőrzés. Az egyszemélyi vezetés elve érvényesült tehát: egy szervezet, egy vezető.

Az egyes oktatási tárgyú törvények módosításáról szóló 2014. évi XXXVI. törvény azonban gyökeres változást hozott az egyszemélyi vezetés tekintetében, hiszen az állami felsőoktatás világába beépítette a kancellári rendszert. Új rendelkezésként az Nftv.-be iktatta a 13/A. \$-t, és annak (1) bekezdésében kimondta, hogy: „az állami felsőoktatási intézményben az intézmény müködtetését a kancellár végzi”, majd a továbbiakban rögzítette a kancellár feladatait és felelősségét. Ezzel párhuzamosan - szintén új rendelkezésként - a rektorról szóló 13. \$(1) bekezdés kiegészítésében kimondta, hogy: „feladatkörében a kancellár az intézmény vezetőjeként és képviselőjeként jár el”, a (2) bekezdés módosításában pedig úgy rendelkezett, hogy a kancellár gyakorolja a munkáltatói jogokat a nem oktatók, kutatók és tanárok esetében. Ráadásul e joghely - egyenlőtlen helyzetet teremtve - a kancellár egyetértéséhez kötötte az oktatók, kutatók és tanárok rektori bérés javadalmazás megállapítását, miközben a kancellár munkáltatói intézkedéseihez nem írta elő a rektor egyetértésének szükségességét.

A 13/A. $\S(2)$ bekezdés b) pontja ezen is továbbment, amikor kimondta, hogy a szenátusnak és a rektornak az „intézmény gazdálkodását, szervezetét és müködését érintő, gazdasági következménnyel járó minden döntéséhez és intézkedéséhez" kell a kancellári hozzájárulás, ami a döntés érvényességének a feltétele.

Jogállását tekintve tehát a kancellár jóval több jogot kapott, mint a rektor, és a pályázati eljárása, illetve a kinevezése során a rektornak - aki, csak emlékeztetésül: a 13. \$(1) bekezdés szerint „az intézmény elsőszámú vezetője és képviselője” - semmiféle beleszólási lehetősége nem volt. Sőt: az intézmény dolgozói által legitim módon megválasztott legmagasabb szintű egyetemi vezető testület, a szenátus döntései érvényességéhez is szükségessé tette a kancellári egyetértést, miközben maga a törvény mondta ki, hogy a kancellár a szenátusnak hivatalból a tagja.

A kancellár az egyetem vezetőjeként nyert tehát beiktatást, ami azt jelenti, hogy 2014. július 24-től egy állami felsőoktatási intézménynek két vezetője lett: a rektor és a kancellár, akik együttműködésre ítéltettek, de a kancellárnak a jogalkotó több jogot biztosított, mint a rektornak és a szenátusnak. Ráadásul - az egyszemélyi vezetés elvének feladásával - nemcsak az intézmény „szakadt” két részre, hanem az intézmény dolgozói köre is, ami megteremtette a két dolgozói kör szembenállását, de legalábbis a szembenállás lehetőségét.

Az újonnan beiktatott Nftv. 13/A. $\$(3)$ bekezdése igen szerény feltételeket támaszt a kancellárral szemben, amikor úgy fogalmaz, hogy: „Kancellári megbízást az kaphat, illetve a kancellári megbízás azzal tartható fenn, aki három éves vezető gyakorlattal és felsőfokú végzettséggel rendelkezik." Csak halkan kérdezem: nem túl kevés, és nem túl alacsony ez a követelmény? Álláspontom szerint túl kevés és túl alacsony is, hiszen egy állami felsőoktatási intézmény rektora melletti (fölötti) másik vezetőjéről van szó. Arról, aki működteti az intézményt, és egyrészt adott esetben több ezer dolgozónak a munkáltatója, másrészt pedig akinek az egyetértése kell a rektor és a szenátus gyakorlatilag minden döntése érvényességéhez. 
Ezek után fölvethető az a kérdés, hogy szükséges volt-e a kancellári rendszer bevezetése a magyar állami felsőoktatásba 2014-ben? Úgy és ahogyan az megtörtént? Álláspontom szerint nem, illetve nem úgy és ahogyan az megtörtént. A kancellárral szemben támasztott követelmények csekély mértéke és a tisztségnek biztosított jogosultságok túlzott mértéke, valamint az egyszemélyi vezetés elvének feladása vezetett, vezethetett oda, hogy a kancellárok többsége rendkívüli gyorsasággal kicserélődött: adott esetben egy intézményben többször is. A jogalkotó alkalmazta-e a partnerség elvét a döntéshozatal során, tehát a döntés meghozatala előtt megkérdezte-e a rektorokat, a Rektori Konferenciát vagy az intézmények szenátusi tagságát a kancellári rendszerről? Ismereteim szerint nem.

5. A 2014. évi XXXVI. törvény 18. $\$(1)$ bekezdéssel módosított Nftv. 13. $\$$ (1) bekezdése úgy rendelkezik, hogy a kancellár döntésével vagy intézkedésével szemben, illetve intézkedésének elmulasztása esetén a rektor a fenntartóhoz intézett kifogással élhet. Ez a látszólag fontos rektori jogosultság azonban életképtelennek bizonyult, ismereteim szerint a gyakorlatban nem müködött, mert nem müködhetett. Ha ugyanis én, az egyetem rektora - a kancellár tájékoztatási kötelezettségének elmulasztása miatt - nem szereztem tudomást a kancellár adott intézkedéséről vagy annak elmulasztásáról, akkor fogalmilag kizárt, hogy élhessek a kifogásolási jogommal.

Mi lehet (mi lehetett volna) a helyes jogalkotói megoldás? Legyen világos: álláspontom szerint nem önmagában a kancellári rendszer fölállítása volt a gond, hanem az, ahogyan azt a jogalkotó bevezette. Hogyan, milyen módon láttam, látom ma is megvalósíthatónak a rendszer müködtetését? Például úgy, hogy a jogalkotó:

- komolyabb feltételeket támaszt a kancellári pályázókkal szemben;

- megtartva az egyszemélyi vezetés elvét, a rektort hatalmazza fel a kinevezési joggal, de minimum elöírja a rektor véleményének előzetes kikérését a döntéshozatal előtt;

- a kancellári döntések meghozatala érvényességét rektori egyetértéshez köti, és ezzel egyidejüleg a kancellárnak előzetes tájékoztatási kötelezettséget ír elő a rektor felé;

- kimondja, hogy minden kancellári döntés és intézkedés hatálybalépéséhez és érvényességéhez szükséges a rektori egyetértés.

Ily módon megszüntethető a rektor és a kancellár között kialakult - álláspontom szerint nem kívánatos - egyensúlytalan állapot. Feltéve persze, hogy a jogalkotó fenntartja a kancellári rendszert az állami egyetemekben, amelyeknek száma egyébként - az állami egyetemek nem állami (magán-) egyetemmé történt átalakítása miatt - rendkívüli módon lecsökkent. A jelenleg hatályos szövegü Nftv. 1. sz. melléklete szerint mindössze hat állami egyetem maradt, szemben a 2014. évi XXXVI. törvény mellékletében felsorolt 20 állami egyetemmel.

\section{KONKLÚZIÓ}

A magyar jogéletben ez idáig három felsőoktatási törvény született. A legutóbbi, pontosan tíz évvel ezelőtt, 2011-ben. Azóta a törvény 900 joghelyen módosult, egy egész sor alapkérdésben is. Ezek közül kiemelkedik a kancellári rendszer 2014. évi bevezetése, amelynek 
következtében az állami felsőoktatási intézmények két vezető alatt kettészakadtak, ráadásul a kancellár több jogosultságot kapott, mint a rektor, sőt még, mint a szenátus is!

A 2014-es év azonban nemcsak a kancellári rendszer bevezetési miatt volt mérföldkő a magyar felsőoktatás életében, hanem azért is, mert ebben az évben született meg Magyarország első felsőoktatás-fejlesztési stratégiája. ${ }^{10}$ Erre alapozva 2016-ban a Kormány elkészítette a felsőoktatás középtávú fejlesztéséről szóló stratégiai dokumentumát, amelyet a magyar felsőoktatás kitörő örömmel fogadott, mert végre láthatóvá (olvashatóvá) vált, hogy a Kormány szerint hol, mivel és hová kell fejleszteni a magyar felsőoktatást. ${ }^{11}$ Első ízben kaptunk tehát a kezünkbe iránytűt, amelynek segítségével elkészíthettük az Egyetem 2020-ig szóló Fejlesztési Tervét, vagyis immár tudtuk, hogy hová hajózunk, mi a célkikötő.

A Fokozatváltás a Felsőoktatásban Stratégia nemcsak hiánypótló jellege miatt, hanem színvonalát és kimunkáltságát tekintve is kimagaslik a hasonló kormányzati stratégiák közül. Mindazonáltal rögzíteni kell azt is, hogy a Stratégia egész sor kérdésben nem adott iránymutatást. Nem vitatható tehát: sikerült a fokozatváltás, de nem biztos, hogy a megfelelő fokozatba kapcsoltunk. Példaként említem azt, hogy a Miskolci Egyetem és a Rektori Konferencia észrevételei ellenére nem szól a „Kiemelt területek” között a társadalomtudományi és a humán képzési területekről (például a bölcsészettudományról, az állam- és jogtudományról stb.), valamint a művészeti képzésekről sem, vagyis megítélésem (megítélésünk) szerint a Stratégia kifejezetten egyoldalú, gazdasági szemléletü. Márpedig világos, hogy kizárólag gazdasági szempontok érvényesítésével nem kezelhetők a magyar felsőoktatás strukturális problémái.

A nem megfelelő fokozatba kapcsolás további példájaként említem, hogy a Kormány által 2016-ban elfogadott és 2030-at mint céldátumot kitűző Stratégia nem beszél az állami felsőoktatási intézmények magánintézménnyé alakításának szándékáról sem, miközben - mint arra korábban már utaltam - az utóbbi két évben, hat egyetem kivételével minden állami egyetem nem állami (magán-) egyetem lett.

Mindezek alapján úgy ítélem meg, hogy lassan, legkésőbb 2022-ben, 2023-ban eljön az ideje egy, az érdekeltek és az érintettek széles körü egyetértésén alapuló hosszú- és egy középtávú felsőoktatás-fejlesztési koncepció kidolgozásának, és egy szintén közmegegyezésen alapuló új felsőoktatási törvény kidolgozásának. Olyannak, amely szervesen illeszkedik az Európai Oktatási Térségbe, valamint - elődeivel szemben - valóban tartósan, komplex módon és megnyugtatóan rendezi a magyar felsőoktatás helyzetét.

$10 \quad$ A Kormány által első olvasatban megtárgyalt Fokozatváltás a felsőoktatásban. A teljesitményelvü felsőoktatás fejlesztésének irányvonalai címü dokumentumot 2014 őszén a Magyar Rektori Konferencia megküldte a felsőoktatási intézmények vezetői részére, várva észrevételeiket. A Miskolci Egyetem üdvözölte a dokumentum megszületését, és egy 2014. október 30-án kelt, hét oldal terjedelmű „,észrevételekben” rögzítette álláspontját, kifogásait és az anyag hiányosságait. Ezek többségét a 2016-ban véglegesített, és a Kormány által 1785/2016. (XII. 16.) számú határozattal jóváhagyott Stratégia megáévá tette.

11 Lásd a Fokozatváltás a felsőoktatásban. Középtávú szakpolitikai stratégia 2016-2020. https://docplayer. hu/110704284-Fokozatvaltas-a-felsooktatasban-kozeptavu-szakpolitikai-strategia cselekvesi-terv.html 


\section{FELHASZNÁLT IRODALOM}

1. Árva Zsuzsanna: A koronavírus hatása a felsőoktatási igazgatásra. In Rixer Ádám (szerk.): A járvány hosszú távú hatása a magyar közigazgatásra. Budapest, Károli Gáspár Református Egyetem, Állam- és Jogtudományi Kar Lörincz Lajos Közjogi Kutatómühely, 2021.349-364.

2. Barakonyi Károly: Rendszerváltás a felsőoktatásban. Bologna-folyamat, modernizáció. Budapest, Akadémiai Kiadó, 2004.

3. Bazsa György: Quo Vadis magyar felsőoktatás? In Hrubos Ildikó - Luda Szilvia - Török Imre (szerk.): Intézményi menedzsment a felsőoktatásban 3. Budapest, Felsőoktatási Gazdasági Szakemberek Egyesülete, 2013. 145-157.

4. Derényi András: A magyar felsőoktatás átalakulása (1989-2008). In Hrubos Ildikó - Luda Szilvia - Török Imre (szerk.): Intézményi menedzsment a felsőoktatásban 3. Budapest, Felsőoktatási Gazdasági Szakemberek Egyesülete, 2013. 69-98.

5. Halász Gábor: A felsőoktatás globális trendjei és szakpolitikai válaszok az OECD országokban és az Európai Unióban. In Hrubos Ildikó - Luda Szilvia - Török Imre (szerk.): Intézményi menedzsment a felsőoktatásban 3. Budapest, Felsőoktatási Gazdasági Szakemberek Egyesülete, 2013. 13-33.

6. Hamza Gábor: Az egyetemi autonómia reformjának kérdéséhez. Magyar Tudomány, 175. (2014), 2. 130-139.

7. Kocsis Miklós: Társadalom - állam - felsőoktatás. A felsőoktatási autonómia értelmezési tartományai. Jogelméleti Szemle, (2010), 3.

8. Kováts Gergely: Az egyetemek fejlödéstörténete - és ennek tanulságai. In Hrubos Ildikó - Luda Szilvia - Török Imre (szerk.): Intézményi menedzsment a felsőoktatásban 3. Budapest, Felsőoktatási Gazdasági Szakemberek Egyesülete, 2013. 45-68.

9. Rixer Ádám: A magyar jogrendszer jellegzetességei 2010 után. Budapest, Patrocinium, 2012.

Jogi források

1. 1949. évi XX. törvény a Magyar Népköztársaság Alkotmányáról

2. 1993. évi LXXX. törvény a felsőoktatásról

3. 2005. évi CXXXIX. törvény a felsőoktatásról (Ftv.)

4. 2010. évi CXXX. törvény a jogalkotásról (Jat.)

5. Magyarország Alaptörvénye (2011. április 25.)

6. 2011. évi CCIV. törvény a felsőoktatásról (Nftv.)

7. 1785/2016. (XII. 16.) Korm. határozat a „Fokozatváltás a felsőoktatásban középtávú szakpolitikai stratégia 2016" elfogadásáról 
Torma András CsC, egyetemi tanár, rector emeritus, Miskolci Egyetem, Állam- és Jogtudományi Kar, Államtudományi Intézet, Közigazgatási Jogi Tanszék. Szakterületei a közigazgatási jog, a közjog, az európai közigazgatás, a jogi informatika, szervezési és vezetési ismeretek és az állam- és jogtudományok. 